\title{
Zakaz missellingu jako przykład zastosowania behawioralnej koncepcji prawa?
}

\section{Wprowadzenie}

Każdego dnia do przeciętnego konsumenta docierają dziesiątki impulsów, propozycji, zachęt dotyczących zakupu określonych towarów i usług. Przedsiębiorcy prześcigają się w promocjach, a także w technikach marketingu, aby osiągnać wyznaczony przez siebie cel, tj. sprzedać towar lub usługę z jak największym zyskiem, a jeżeli to możliwe pozyskać konsumenta także na przyszłość. Jako przykład wskazać można sprzedaż drukarki komputerowej dołączanej w promocyjnej cenie do komputera, której używanie wymusi w przyszłości zakup materiałów eksploatacyjnych, których cena niejednokrotnie przewyższa wartość samej drukarki. Co więcej, bardzo często jest tak, że ów dodatkowy towar oferowany „w promocji” jest konsumentowi w ogóle niepotrzebny i wymusza wymianę już posiadanego, przyczyniając się tym samym do zwiększenia liczby odpadów, z którymi współczesny świat ma obecnie poważny problem. Czytelnik śledzący powyższy wywód, zapyta być może o jego cel. Co bowiem wspólnego ma drukarka z tytułowym missellingiem, a więc instytucją charakterystyczną w szczególności dla rynku finansowego i odnoszącą się do kupna usługi finansowej nieodpowiadającej potrzebom klienta? Jak się okazuje, zarówno sprzedaż niepotrzebnego towaru, jak i usługi finansowej mają ze sobą wiele wspólnego. W obydwóch przypadkach wskazać można kilka analogicznych elementów, w tym zwłaszcza niekiedy nachalną sprzedaż, wykorzystywanie określonych jej technik, a także, co ważne, osobiste cechy kupujących, u których chęć posiadania zwycięża z racjonalnością. 
W przypadku rynku finansowego i produktów (usług) na nim oferowanych dodatkową cechą, jaką należy wskazać, jest skomplikowanie jego materii, a także silna pozycja podmiotów finansowych wobec ich klientów, które to podmioty wyposażone są w doskonałe zaplecze finansowo-intelektualno-prawne. Słabość konsumentów usług finansowych spowodowała, że ich ochrony podjęło się państwo, wprowadzając zakaz praktyki missellingu, w którym to zakazie autor zauważa także przejaw uwzględnienia $\mathrm{w}$ procesie tworzenia prawa doświadczeń przedstawicieli nauki głoszących potrzebę patrzenia na ten proces przez pryzmat doświadczeń nauk behawioralnych. Ponadto analizowana w niniejszym artykule, pozornie niewielka, poprawka do Ustawy z dnia 16 lutego 2007 r. o ochronie konkurencji i konsumentów ${ }^{1}$ stała się przyczynkiem do ożywionej debaty przedstawicieli praktyki oraz teorii prawa zarówno prywatnego, jak i publicznego ${ }^{2}$. Analiza najważniejszych wątków tejże dyskusji skłania do refleksji nad źródłami efektywności missellingu oraz możliwością znalezienia efektywnego sposobu walki z nim. Czy nie nadszedł bowiem czas na spojrzenie prawdzie w oczy i stwierdzenie, że dotychczasowy paradygmat racjonalnego konsumenta jest już nieaktualny? Czy w dobie rosnącego znaczenia rynków finansowych w życiu codziennym, skomplikowania oferowanych na nim instrumentów, nie należy dążyć do stworzenia w Polsce wyspecjalizowanego organu (Komisji Ochrony Klientów Rynku Finansowego), w którego zakresie kompetencji byłaby ochrona uczestników rynku finansowego?

${ }^{1}$ Dz.U. 2017, poz. 229 ze zm., dalej „u.o.k.i.k.".

${ }^{2} \mathrm{~W}$ ostatnich latach widoczna jest tendencja do przenikania się tych dwóch sfer prawa - publicznej i prywatnej, których dotychczasowy podział i zakres był przejrzysty oraz prosty do ustalenia. Impulsem do zmian stało się m.in. pojawienie się wyszukanych konstrukcji, w szczególności ekonomicznych, które stając się wyzwaniem dla prawodawcy, wymusiły na nim zmianę filozofii regulacyjnej. Omawiana tendencja jest widoczna przede wszystkim $w$ rozwijających się od kilku lat z powodzeniem nowych dziedzinach prawa, za które uznać należy prawo rynku finansowego (o charakterze publicznoprawnym) oraz prawo rynku usług finansowych (o charakterze prywatnoprawnym). Analizowana w niniejszym opracowaniu koncepcja missellingu jest doskonałym przykładem połączenia tych dwóch dziedzin, bowiem prawodawca, wyposażając w uprawnienia o charakterze ingerencyjnym podmiot publicznoprawny (Prezesa Urzędu Ochrony Konkurencji i Konsumenta), oddziałuje tym samym na relacje o charakterze prywatnoprawnym, jakimi są te łączące instytucję finansową z jej klientami oraz konsumentami. Cieszy fakt, że zarówno przedstawiciele prawa prywatnego, jak i publicznego zauważają wskazane, dokonujące się zmiany. Jako przykład należy podać prace: M. Fedorowicz, Rola i zadania teorii prawa rynku finansowego UE, „Bezpieczny Bank” 2016, nr 1, passim; R. Szczepaniak, Węzłowe problemy stosowania prawa prywatnego w prawie publicznym, „Ruch Prawniczy, Ekonomiczny i Socjologiczny" 2016, nr 4, passim. 
Dotyczy to przede wszystkim tych mniej profesjonalnych uczestników, powszechnie określanych mianem "konsumentów usług finansowych", którzy każdego dnia ulegają pokusie nabycia usług (towarów) nieodpowiadających ich potrzebom i możliwościom.

\section{O istocie europejskiego rynku finansowego}

Dla zrozumienia istoty missellingu i konsekwencji prawnych, jakie on rodzi, dyskusję na jego temat osadzić należy w szerszym kontekście, tj. kontekście rynku finansowego Unii Europejskiej (UE). Polska, będąc częścią tejże wspólnoty krajów, wraz ze swą akcesją do niej zobowiązała się bowiem przyjąć jej dotychczasowy i przyszły dorobek prawny, w tym także i ten dotyczący unijnego rynku finansowego. Pojęcie tego rynku było zresztą przedmiotem wielu dyskusji, w których zastanawiano się nad tym, czy rynek ten uznać można za twór jednolity, czy też raczej za strukturę rynków finansowych państw członkowskich, dla których wspólnym mianownikiem jest prawo europejskie. Autor niniejszego tekstu należy do grona zwolenników drugiej z wymienionych koncepcji, widząc w rynku finansowym Unii Europejskiej swego rodzaju amalgamat rynków krajowych, które tworzą byt umownie nazywany rynkiem finansowym Unii Europejskiej. Jednocześnie zgodzić się należy z teza, że tak ujmowany rynek musi być uznawany za część większej całości, czyli zdefiniowanego w art. 26 ust. 2 Traktatu o funkcjonowaniu Unii Europejskiej $^{3}$ rynku wewnętrznego ${ }^{4}$, a więc obszaru bez granic wewnętrznych, w którym jest zapewniony swobodny przepływ towarów, osób, usług i kapitału, zgodnie z postanowieniami Traktatów. Przepis ten, choć powszechnie znany i wielokrotnie cytowany, ma jednak fundamentalne znaczenie dla filozofii regulacyjnej dotyczącej unijnego rynku finansowego. Jest ona tworzona sukcesywnie i konsekwentnie od lat osiemdziesiątych XX w., kiedy to wdrożone zostało przez władze unijne tzw. podejście New Approach ${ }^{5}$, w którym określone zostały priorytety w zakresie reformy tego rynku na najbliższe lata. Dynamizm wydarzeń na świecie, w tym przede wszystkim kryzys finansowy z roku

${ }^{3}$ Traktat o funkcjonowaniu Unii Europejskiej - wersja skonsolidowana, Dz.Urz. UE C 326/47 z 26 X 2012 r., dalej „TFUE”.

${ }^{4}$ C. Kosikowski, Finanse i prawo finansowe Unii Europejskiej, Warszawa 2014, s. 270-272.

${ }^{5}$ Więcej na ten temat w: T. Nieborak, Aspekty prawne funkcjonowania rynku finansowego Unii Europejskiej, Warszawa 2008, s. 70-87. 
2008, wymusił na władzach unijnych rewizję wcześniejszych planów i elastyczne dostosowywanie ich do zmieniającej się rzeczywistości. Przykładowym efektem owych działan ad hoc jest powołanie do życia w roku 2010 Europejskiego Systemu Nadzoru Finansowego, którego koncepcja prawna osadzona została m.in. na cytowanym wcześniej art. 26 ust. 2 TFUE oraz na niezwykle istotnym art. 114 ust. 1 TFUE, który z kolei dał uzasadnienie do wyposażenia organów nadzorczych tworzących wspomniany system $\mathrm{w}$ określone (i niejednokrotnie nowatorskie) instrumenty nadzorczo-kontrolne ${ }^{6}$. Moment wprowadzenia nowych unijnych struktur nadzorczych uznać należy za początek rewolucji regulacyjnej Unii Europejskiej dotyczącej tamtejszego rynku finansowego. Trwa ona do dnia dzisiejszego, a jej efektem jest przyjęcie kilkudziesięciu aktów prawnych obejmujących najważniejsze segmenty rynku finansowego (bankowy, kapitałowy oraz ubezpieczeniowy), wprowadzenie w życie koncepcji Unii Bankowej, a obecnie także Unii Rynków Kapitałowych oraz rozpoczęcie prac nad aktami prawnymi, których przedmiot regulacji obejmować ma innowacje finansowe tworzone przez rynek, w tym np. kryptowaluty ${ }^{7}$, shadow banking ${ }^{8}$ czy też high frequency trading ${ }^{9}$.

Uwagę zwrócić należy przy tym na to, iż od samego początku kreowania unijnego rynku finansowego prawodawca przykładał dużą wagę do kwestii dotyczących tzw. detalicznego rynku finansowego, który w odróżnieniu od hurtowego rynku finansowego (płatności wielkokwotowych) związany był z operacjami, w których jedną ze stron był konsument. W nomenklaturze unijnej ten segment rynku określany jest także jako detaliczny lub konsumencki. Zanim zaprezentowana zostanie jego istota, warto w tym miejscu wskazać na przykład w postaci dyrektywy w sprawie usług płatniczych, powszechnie określanej jako PSD2, której pełna implementacja w krajach członkowskich nastąpić ma do dnia 13 stycznia 2018 r. Wybór tego aktu nie jest przypadkowy, gdyż jest on doskonałym przykładem prokonsumenckiego nastawienia

${ }^{6}$ Więcej na ten temat w: M. Fedorowicz, Nadzór nad rynkiem finansowym Unii Europejskiej, Warszawa 2013, s. 112-130.

${ }^{7}$ S. Bala, T. Kopyściański, W. Srokosz, Kryptowaluty jako elektroniczne instrumenty płatnicze bez emitenta. Aspekty informatyczne, ekonomiczne i prawne, Wrocław 2016.

${ }^{8}$ W. Srokosz, Shadow banking a regulacje prawne instytucji parabankowych w Polsce, w: Wyzwania regulacji rynków finansowych. Unia bankowa. Kontrahenci centralni. Parabanki, pod red. W. Rogowskiego, Kraków-Warszawa 2013, s. 193-204.

9 A. Chłopecki, Ł. Malanowski, Handel algorytmiczny, "Monitor Prawa Bankowego" 2014, nr 7-8, s. 65-71. 
prawodawcy unijnego, który konstrukcję dyrektywy (ale i jej poprzedniczki) oparł na dwóch filarach, którymi są: jej prokonsumencki charakter oraz neutralność technologiczna. Pierwszy z nich materializuje się $\mathrm{w}$ rozwiązaniach regulujących m.in. problematykę terminowości realizacji zleceń klienta przez instytucję finansowa, odpowiedzialności stron, ochrony danych, a także zakazu pobierania dodatkowych opłat. Z kolei istota neutralności technologicznej zasadza się na przekonaniu, że prawo tworzone powinno być w taki sposób, aby nie ograniczać technologicznych aspektów rozwoju określonych usług finansowych, co w praktyce oznacza tworzenie stosunkowo "pojemnych" definicji określonych instytucji (np. pieniądza elektronicznego ${ }^{10}$ ). Analiza dokumentów unijnych wydaje się potwierdzać tezę o protechnologicznym podejściu Unii Europejskiej, która w usługach o charakterze cyfrowym, takich jak: bankowość mobilna, pożyczki bezpośrednie (ang. peer-to-peer lending) czy porównywarki internetowe, widzi szansę na integrację wspomnianego detalicznego rynku finansowego. Wyraz temu dała Komisja Europejska w opublikowanym w marcu 2017 r. dokumencie pt. „Plan działania w sprawie detalicznych usług finansowych: szersza oferta i lepsze produkty"11. Podstawowa idea tego dokumentu sprowadza się do twierdzenia, że istnieje konieczność podjęcia dalszych kroków w kierunku utworzenia prawdziwie jednolitego rynku detalicznych usług finansowych opartego na technologii, na którym konsumenci moga uzyskać najlepsze oferty, a ponadto są dobrze chronieni. Jednocześnie Komisja Europejska zidentyfikowała trzy główne aspekty, których realizacja przyczyni się do wcielenia w życie powyżej wskazanego postulatu. Są to: „1. zwiększenie zaufania konsumentów i wzmocnienie pozycji konsumenta przy dokonywaniu zakupu usług w kraju macierzystym lub w innych państwach członkowskich; 2. ograniczenie przeszkód prawnych i regulacyjnych mających wpływ na działalność przedsiębiorstw świadczących usługi finansowe za granicą; oraz 3. wspieranie rozwoju

${ }^{10}$ Zgodnie z art. 2 pkt 21a Ustawy z dnia 19 VIII 2011 r. o usługach płatniczych (tekst jedn. Dz.U. 2016, poz. 1572 ze zm.) pieniądzem elektronicznym jest wartość pieniężna przechowywana elektronicznie, w tym magnetycznie, wydawana, z obowiązkiem jej wykupu, w celu dokonywania transakcji płatniczych, akceptowana przez podmioty inne niż wyłącznie wydawca pieniądza elektronicznego. Więcej na ten temat w: A. Zalcewicz, B. Bator, Ustawa o ustugach płatniczych. Komentarz, Warszawa 2016, s. 76-77.

${ }^{11}$ Komunikat Komisji do Parlamentu Europejskiego, Rady, Europejskiego Banku Centralnego, Europejskiego Komitetu Ekonomiczno-Społecznego i Komitetu Regionów. Plan działania w sprawie detalicznych ustug finansowych: szersza oferta i lepsze produkty, Bruksela, 23 III 2017 r., $\operatorname{COM}(2017) 139$ final. 
innowacyjnego środowiska cyfrowego, które pomoże przezwyciężyć niektóre istniejące bariery dla jednolitego rynku"12.

Postulaty te stanowią rozwinięcie tych zgłoszonych już kilka lat wcześniej w innym niezwykle istotnym dokumencie, tj. „Komunikacie Komisji do Parlamentu Europejskiego, Rady, Europejskiego Komitetu Ekonomiczno-Społecznego i Komitetu Regionów. Zreformowany europejski sektor finansowy"13. Jeden z rozdziałów tego dokumentu dotyczy zwiększenia przejrzystości i odpowiedzialności sektora finansowego oraz ochrony konsumentów w celu zapewnienia integralności rynku i przywrócenia zaufania konsumentów. Zakłada się przy tym m.in.: ustanowienie ogólnounijnych standardów dotyczących odpowiedzialnego udzielania kredytów hipotecznych; ulepszenie zasad dotyczących ujawniania informacji oraz podwyższenie standardów w zakresie doradztwa finansowego i dystrybucji produktów finansowych; zwiększenie ochrony aktywów inwestorów detalicznych; zwiększenie przejrzystości i porównywalności opłat za prowadzenie rachunku bankowego, wprowadzenie łatwej i szybkiej procedury przeniesienia rachunku bankowego oraz powszechnego dostępu do podstawowego rachunku bankowego. Środki te mają na celu zwiększenie zaufania konsumentów do rynków i produktów finansowych ${ }^{14}$. Zaufanie owo stanowi w ocenie autora podstawową wartość rynku finansowego, której osiągnięcie wymaga $z$ kolei ochrony innych fundamentalnych dla rynku finansowego dóbr, za które powszechnie uważa się stabilność i bezpieczeństwo. Pisząc o zaufaniu, należy podkreślić, że definiując je jako określoną pozytywną relację pomiędzy co najmniej dwiema osobami, zawiera ono w sobie określony ładunek społeczny i etyczny (spośród których w szczególności ten ostatni towarzyszy dyskusji na temat zasadności wprowadzenia zakazu missellingu). Zarówno ładunek społeczny, jak i etyczny (podobnie jak prawo) nierozerwalnie łączą się z zasadami i normami postępowania przyjętymi w danym czasie i w danym środowisku. Tym samym, kształtując filozofię regulacyjną rynku finansowego, przede wszystkim w zakresie praw (i obowiązków) konsumentów, nie sposób nie uwzględnić w niej elementów etycznych, ale także behawioralnych.

${ }^{12}$ Ibidem, s. 4.

${ }^{13}$ Więcej na ten temat zob. Komunikat Komisji do Parlamentu Europejskiego, Rady, Europejskiego Komitetu Ekonomiczno-Społecznego i Komitetu Regionów. Zreformowany europejski sektor finansowy, Bruksela, 15 V 2014 r., COM(2014) 279 final, s. 8.

${ }^{14}$ Ibidem. 
O pierwszym z nich wspomina się w kolejnym dokumencie unijnym, którego narrację określić można jako wyjątkową. Mowa tu o opracowanej w ubiegłym roku opinii Europejskiego Komitetu Ekonomiczno-Społecznego w sprawie "Gospodarka na rzecz dobra wspólnego - zrównoważony model gospodarczy ukierunkowany na spójność społeczną"15. $\mathrm{W}$ dokumencie tym znalazły się propozycje dotychczas niespotykane, których realizacja ma za cel wspieranie etycznej konsumpcji i świadomości europejskich konsumentów oraz zwiększanie różnorodności ekosystemu finansowego poprzez promowanie sieci etycznych banków i rynków papierów wartościowych w całej UE. Planuje się przy tym wprowadzenie oznakowania etycznego produktów, które służyłoby informowaniu o etycznym postępowaniu przedsiębiorstw na europejskim wspólnym rynku, za pośrednictwem wspólnego systemu oznakowania etycznego, opisującego wkład przedsiębiorstwa we wspólne dobro. Oczywiście, wyobrazić można sobie sytuację, w której tego rodzaju opis dotyczyłby i produktów finansowych. Jego przygotowanie wymagałoby przy tym uwzględnienia drugiego z wymienionych wcześniej elementów kreujących filozofię regulacyjną rynku finansowego, którymi w opinii autora są aspekty behawioralne dotyczące przede wszystkim konsumentów usług finansowych ${ }^{16}$. Ci bowiem, jak zostało to już zasygnalizowane, są najbardziej podatni na pokusy płynące z rynku, a materializujące się $\mathrm{w}$ zachowaniach charakteryzujących tytułowy misselling. Czy nieuczciwy sprzedawca oferujący sprzedaż skomplikowanego instrumentu finansowego osobie starszej nie wykorzystuje jej słabości behawioralnych? A może widzi w niej modelowy przykład konsumenta, jaki od wielu lat jest promowany w Unii Europejskiej? Konsumenta ostrożnego i rozważnego (ang. reasonably circumspect consumer), umiejącego należycie wykorzystać przekazywane mu informacje, na podstawie których podejmuje on określone (racjonalne) decyzje? ${ }^{17}$ Opisując go,

${ }^{15}$ Gospodarka na rzecz dobra wspólnego - zrównoważony model gospodarczy ukierunkowany na spójność społeczna, Dz.Urz. UE C 13/26 z 15 I 2016 r.

${ }^{16}$ Zob. A. Szyszka, Behawioralne aspekty kryzysu finansowego, "Bank i Kredyt” 2009, t. 40, nr 4, s. 14; idem, Finanse behawioralne. Nowe podejście do inwestowania na rynku kapitałowym, Poznań 2009, s. 44-97; A. Biela, Informacja i decyzja w ekonomii behawioralnej, Lublin 2011, s. 33-37; Ch. Jolls, Behavioral Law and Economics, "John M. Olin Center for Studies in Law, Economics, and Public Policy, Yale Law School, Research Paper" 2006, no. 342, s. 3; Ch. Jolls, C.R. Sunstein, Debiasing Through Law, „NBER Working Paper Series, Working Paper 11738" 2005, no. 11738, s. 34.

17 Zob. np.: wyrok Europejskiego Trybunału Sprawiedliwości (ETS) z 20 II 1979 r. w sprawie C-120/78 Rewe-Zentral AG v. Bundesmonopolverwaltung für Branntwein, ECR 
wskazuje się, że jest on należycie poinformowany, świadomy, rozsądny, uważny, ostrożny, krytyczny, spostrzegawczy i samodzielny, ale także należycie wyedukowany oraz podejrzliwy ${ }^{18}$. Jednym słowem, jest on niczym konsument-supermen, który - jak słusznie zauważa A. Mokrysz-Olszyńska - w praktyce okazuje się niekoniecznie rozsądny, jednak zawsze dobrze poinformowany ${ }^{19}$. Model ten jest oczywiście wyidealizowany, a w jego opisie nie bierze się pod uwagę różnic w definiowaniu np. osoby racjonalnej i osoby świadomej, z których ostatnia bierze pod uwagę zależności zachodzące pomiędzy zjawiskami wewnętrznymi (procesami myślowymi) a zjawiskami zewnętrznymi ${ }^{20}$.

$Z$ tego powodu autor w pełni zgadza się z tezą D. Cymana, że "proces informowania konsumenta powinien uwzględniać brak jego profesjonalizmu (co dowodzą osiągnięcia nauk behawioralnych) w stopniu umożliwiającym podjęcie właściwej decyzji i wyboru oferty jak najbardziej odpowiadającej jego celom i możliwościom. Nie może jednak przytłaczać nadmiarem szczegółów. Zmianie powinien ulec również model konsumenta, z rozsądnego na świadomego. W dobie powszechnego korzystania z technologii coraz bardziej złożonych mechanizmów dokonywania operacji bankowych, konsument wciąż zachowując swój nieprofesjonalizm, świadomy jest jednak zasad działania różnorodnych instrumentów finansowych. Za niewłaściwy uznać należy przyjmowany niekiedy model klienta nierozsądnego, realizowany poprzez zastąpienie nakazu informowania konsumenta zakazem stosowania określonych praktyk lub postanowień umownych, obciążonych rygorem nieważności lub bezskuteczności tych postanowień. Jest on sprzeczny z samą ideą

1979, s. 00649; wyrok ETS z 22 V 1992 r. w sprawie C-290/90 Komisja v. Niemcy, ECR 1992, s. I-3874; wyrok ETS z 6 VII 1995 r. w sprawie C-470/93 Verein gegen Unwesen In Handel und Gewerbe Köln v. Mars GmbH, ECR 1995, s. I-1923; wyrok ETS z 2 II 1994 r. w sprawie C-315/92 Verband Sozialer Wettbewerb v. Clinique Laboratories SNC Lauder Cosmetics $\mathrm{GmbH}$, ECR 1994, s. I-317. Te i inne sprawy zostały szczegółowo omówione w publikacji A. Tischner, Model przeciętnego konsumenta w prawie europejskim, „Kwartalnik Prawa Prywatnego" 2006, z. 1, s. 199-243.

${ }^{18}$ S. Lazarewicz, Konsument - pojęcie i jego europejski model, w: Ochrona konsumenta w prawie polskim i Unii Europejskiej, pod red. M. Królikowskiej-Olczak, B. Pachucy-Smulskiej, Warszawa 2013, s. 33-34.

${ }^{19}$ A. Mokrysz-Olszyńska, Europejska strategia ochrony konsumenta przez informacje, w: Studia i rozprawy. Ksiegga jubileuszowa dedykowana profesorowi Andrzejowi Całusowi, pod red. A. Janika, Warszawa 2009, s. 636.

${ }^{20}$ Powyższy problem został szczegółowo omówiony w: T. Nieborak, Creation and Enforcement of Financial Market Law in the Light of the Economisation of Law, Poznan 2016, s. $175-180$. 
ochrony konsumenta, która nie powinna ograniczać ani eliminować jego aktywności, ale umożliwić mu podjęcie optymalnej decyzji"21.

Konieczna jest zatem, nawiązując do powyższego cytatu, redefinicja dominującego w Unii Europejskiej paradygmatu konsumenta racjonalnego i zastąpienie go koncepcją konsumenta świadomego, który zdaje sobie sprawę zarówno z zachodzących zjawisk wewnętrznych (swoich emocji, procesów myślowych), jak i zjawisk mających miejsce $\mathrm{w}$ środowisku zewnętrznym (np. na rynku finansowym) ${ }^{22}$. Opierając się na tej wiedzy, wspartej także przez działania edukacyjne, konsument taki powinien być w stanie reagować na wymienione zjawiska i przejmować część ryzyka związanego z podejmowanymi decyzjami. I choć nieprofesjonalny i nie zawsze racjonalny, to jednak świadomy jest on złożoności otaczającego go świata i musi brać pod uwagę konsekwencje i ryzyko swoich działań. Rolą zaś państwa jest stworzenie takich warunków, które zapewnią przy tym jego ochronę przed nieuczciwymi działaniami podmiotów finansowych, takimi jak misselling. Pamiętać bowiem należy, że ochrona konsumentów traktowana jest także jako element definicyjny bezpieczeństwa rynku usług finansowych ${ }^{23}$.

Biorąc pod uwagę reputację sektora usług finansowych ${ }^{24}$, dopuścić można nawet - na co zwrócił uwagę w swym orzeczeniu Trybunał Sprawiedliwości Unii Europejskiej (sprawa C-384/94 Alpine Investments $B V$ v. Minister Finansó $w^{25}$ ) - ograniczenie swobody świadczenia określonych usług ${ }^{26}$. Uczynił to holenderski prawodawca, wprowadzając przepisy ograniczające swobodę świadczenia usług tzw. cold calling (oferowanie usług finansowych przez telefon) w celu ochrony dobrego

${ }^{21}$ D. Cyman, Elektroniczne instrumenty płatnicze a bezpieczeństwo uczestników rynku finansowego, Warszawa 2013, s. 208.

22 Ibidem, s. 208-209.

${ }^{23}$ E. Rutkowska-Tomaszewska, Ochrona prawna klienta na rynku ustug bankowych, Warszawa 2013, s. 84-85. Zob. także eadem, Nieuczciwe praktyki na rynku bankowych ustug konsumenckich, Warszawa 2011, passim.

${ }^{24}$ P. Craig, G. de Búrca, EU Law, Text, Cases and Materials, Oxford 2002, s. 821.

${ }^{25}$ Wyrok ETS z $10 \mathrm{~V} 1995$ r. w sprawie C-384/93 Alpine Investments BV v. Minister van Financiën, https://curia.europa.eu/arrets/TRA-DOC-PL-ARRET-C-03841993-200406764-05_00.html (dostęp: 20 VII 2017 r.) .

${ }^{26}$ Zob. pkt 46 tego orzeczenia: „Jak słusznie podniósł rząd niderlandzki, w przypadku 'cold calling' osoba fizyczna, przeważnie zaskoczona, nie jest w stanie rozpoznać ryzyka związanego z charakterem proponowanych jej transakcji ani porównać jakości i cen usług zwracającej się do niej firmy z ofertami konkurentów. Ponieważ towarowy rynek terminowy ma wysoce spekulacyjny charakter i jest $z$ trudem zrozumiały dla mało świadomego inwestora, należało wyłączyć go z najbardziej agresywnych sposobów akwizycji". 
imienia narodowego sektora finansowego, co stało się impulsem dla sporu sądowego zakończonego orzeczeniem w cytowanej sprawie. Jej przytoczenie $\mathrm{w}$ tym miejscu nie jest przypadkowe, gdyż nawiązuje pośrednio do problemu missellingu, którego zakaz od niedawna jest unormowany przez polskiego prawodawcę.

\section{Misselling - głos w dyskusji}

W dniu 15 marca 1962 r. ówczesny prezydent Stanów Zjednoczonych J.F. Kennedy, stojąc przed Kongresem Stanów Zjednoczonych, rozpoczął swe przemówienie od sławnego zdania: „Consumers, by definition, include us all..." („Wszyscy, z definicji, jesteśmy konsumentami...”) i jak się dziś uważa, dał początek nowej erze w zakresie ochrony konsumenta, któremu zagwarantowana miała zostać ochrona zawierająca cztery podstawowe prawa, a mianowicie: prawo do bezpieczeństwa, prawo do informacji ${ }^{27}$, prawo wyboru spośród różnych produktów i usług po konkurencyjnych cenach oraz prawo wyrażania opinii. Jak zostało to wykazane, ochrona stanowi także przedmiot zainteresowania europejskiego prawodawcy, który w ostatnich latach zaczął obejmować nią także rynek finansowy, który choć prosty w rozumieniu, okazuje się niezwykle trudny do ujęcia w ramy prawne. Twierdzenie, że takowe muszą istnieć, wydaje się współcześnie powszechnie akceptowalne i mające swe uzasadnienie $w$ licznych przesłankach regulacji rynku finansowego. $Z$ punktu widzenia omawianej problematyki jedną $z$ nich, wartą przybliżenia, jest możliwość wystąpienia zjawiska tzw. „zamknięcia w sieci" (ang. gridlock). Polega ono na tym, że mimo iż dana instytucja finansowa ma wiedzę na temat tego, w jaki sposób powinna postępować wobec swoich klientów, to jednak podejmuje ryzykowne działania zabezpieczające jej krótkoterminowe zyski, nie mając pewności, czy jej konkurenci nie postąpią w ten sam sposób. W konsekwencji, gdy i inne instytucje będą postępować podobnie, będąc zamkniętymi w przysłowiowej sieci, przy braku odpowiednich regulacji wszyscy mogą ponieść straty, które będą wynikiem owych ryzykownych działań ${ }^{28}$. Przykładem tego rodzaju stadnego zachowania może być właśnie

${ }^{27}$ Zob. także B. Pachuca-Smulska, Prawo do informacji i edukacji podstawa ochrony interesów konsumenta, w: Ochrona konsumenta w prawie polskim..., s. 42-47.

${ }^{28}$ D. Llewellyn, The Economic Rationale for Financial Regulation, Financial Services Authority, "Occasional Paper Series 1” April 1999, s. 9-10. Zob. także G. Borys, Dyskusja wokót 
misselling tłumaczony w języku polskim jako „chybiona sprzedaż”, „zła sprzedaż", a sprowadzający się w uproszczeniu do sprzedaży usługi lub produktu, który nie odpowiada potrzebom konsumenta. Mimo że $z$ etycznego punktu widzenia jest ona niedopuszczalna, to jest jednak praktykowana przez większość uczestników rynku finansowego, którzy w sytuacji rezygnacji z niej utraciliby potencjalne zyski, przejęte z pewnością przez konkurencję. Idąc z „duchem czasu”, korzystają przy tym $\mathrm{z}$ "dobrodziejstw” asymetrii informacji oraz asymetrii podziału ryzyka, a więc zjawisk od lat towarzyszących rynkowi finansowemu. W pierwszym przypadku jedna strona (zazwyczaj instytucja finansowa) wykorzystuje swą przewagę informacyjną na temat istoty oferowanego produktu (usługi) wobec drugiej (zazwyczaj konsumenta). W efekcie pojawić się może drugie $z$ negatywnych zjawisk, tj. asymetria podziału ryzyka, a więc sytuacja, gdy instytucje finansowe, czerpiąc z niepełnego i niewłaściwego informowania swych klientów, mogą same w przyszłości ponieść faktyczne konsekwencje ryzyka wynikającego z takiego postępowania. Jak słusznie uważa A. Jurkowska-Zeidler, omówione postępowanie może mieć dotkliwe skutki o znaczeniu systemowym i stanowić zagrożenie dla stabilności finansowej oraz bezpieczeństwa rynku finansowego ${ }^{29}$.

Oczywiście, sprzedaż ta dotyczyć może rozmaitych przedmiotów, a więc nie tylko tych charakterystycznych dla rynku finansowego w postaci instrumentów finansowych. Jako przykład wskazać można sprawy, które były i są przedmiotem zainteresowania organów mających chronić interesy konsumentów, w tym zwłaszcza Prezesa Urzędu Ochrony Konkurencji i Konsumenta (dalej „UOKiK”) czy też Rzecznika Finansowego. $\mathrm{W}$ swych analizach podmioty te zwracały uwagę na problem nieuczciwych praktyk sprzedaży garnków, pościeli, energii, a w ostatnim okresie także polis ubezpieczenia sprzętu elektronicznego ${ }^{30}$, kiedy to sprzedawcy niejednokrotnie wywierali behawioralny wpływ na konsumenta,

regulacji i nadzoru nad sektorem finansowym, w: Rynek finansowy - szanse i zagrożenia rozwoju, pod red. P. Karpusia, J. Węcławskiego, Lublin 2005, s. 9-10; Ch.A.E. Goodhart, Some Regulatory Concerns, w: The Emerging Framework of Financial Regulation, ed. by Ch.A.E. Goodhart, London 1998, s. 218-223.

${ }^{29}$ A. Jurkowska-Zeidler, Konsekwencje zmian w systemie ochrony konsumenta ustug finansowych, "Gdańskie Studia Prawnicze" 2016, t. 36, s. 194. Zob. także eadem, Asymetria ryzyka a zasady sprawiedliwości społecznej na tle problemu kredy tów we frankach szwajcarskich, „Gdańskie Studia Prawnicze” 2016, t. 35, s. 131-151.

${ }^{30}$ Zob. Raport Rzecznika Finansowego. Ubezpieczenie sprzętu elektronicznego, Warszawa 2016. 
stosując w tym celu reguły identyfikowane jako: reguła wzajemności, niedostępności, społecznego dowodu słuszności, autorytetu oraz sympatii. Potwierdza to wyrażoną wcześniej wątpliwość co do optymistycznej wizji konsumenta jako podmiotu racjonalnego i oświeconego. Dlatego zgodzić się należy z poglądem, że jego ochrona wymaga szerszej optyki, uwzględniającej kontekst ochrony określonych dóbr i wartości niezbędnych do funkcjonowania i rozwoju danego segmentu rynku - w tym przypadku rynku finansowego ${ }^{31}$. Niezbędna jest więc wiedza na temat specyfiki usług finansowych będących przedmiotem umowy, które potocznie określane są jako pojęcie „instrumentów finansowych" $^{\prime 2}$. Tym bardziej że kształtowanie koncepcji konsumenta w Unii Europejskiej następowało poprzez analizę jego sytuacji w przypadku oferowania mu "tradycyjnych" dóbr konsumpcyjnych (kosmetyków, batoników itp.), za jakie z całą pewnością nie mogą zostać uznane instrumenty finansowe. Również w literaturze przedmiotu reprezentowany jest pogląd, że świadczenia finansowe są produktami porównywalnymi do dóbr konsumenckich i jako takie powinny podlegać regułom do nich zbliżonym (np. ze względu na odpowiedzialność za nie) ${ }^{33}$. Autor niniejszego opracowania skłania się jednak do zaliczenia usług finansowych do kategorii dóbr zaufania (ang. credence goods), a więc takich, których jakości nabywca nie jest w stanie ustalić z momentem nabycia (a nawet po nim), czego niejednokrotnie ponosi konsekwencje ${ }^{34}$. Dlatego w kształtowaniu polityki informacyjnej względem konsumentów tychże usług tak wiele uwagi poświęca się procesowi informacyjnemu, który uwzględniać będzie przybliżenie natury oferowanych produktów ${ }^{35}$. Tendencja ta jest widoczna w większości segmentów rynku finansowego: od rynku bankowego ${ }^{36}$, przez kapitałowy ${ }^{37}$, na rynku płatniczym ${ }^{38}$ skończywszy. Dominuje na nim koncepcja regulacji poprzez

${ }^{31}$ E. Rutkowska-Tomaszewska, Ochrona prawna klienta..., s. 27.

32 Problematyka ta omówiona została również w: T. Nieborak, Tworzenie i stosowanie prawa rynku finansowego a proces ekonomizacji prawa, Poznań 2016, s. 200-216.

${ }^{33}$ P. Tereszkiewicz, Obowiazki informacyjne w umowach o ustugi finansowe. Studium instrumentów ochronnych w prawie prywatnym i prawie unijnym, Warszawa 2014, s. 33-34.

${ }^{34}$ Ibidem, s. 38.

${ }^{35}$ Został on poddany wyczerpującej i niezwykle cennej zarówno z praktycznego, jak i teoretycznego punktu widzenia analizie w przytaczanej powyżej monografii P. Tereszkiewicza Obowiazki informacyjne w umowach o ustugi finansowe...

${ }^{36}$ Z. Ofiarski, Prawo bankowe, Warszawa 2017, passim.

${ }^{37}$ P. Wajda, Efektywność informacyjna rynku giełdowego, Warszawa 2011, passim.

${ }^{38}$ A. Zalcewicz, Nadzór Komisji Nadzoru Finansowego nad rynkiem usług płatniczych nowe uregulowania prawne w zakresie kompetencji i zadań nadzorczych, w: Nadzór nad rynkiem 
informację, której elementy odnajdujemy także w przepisie art. 24 ust. 2 pkt 4 u.o.k.i.k., w którym prawodawca za praktykę naruszającą zbiorowe interesy konsumentów uznał zachowanie przedsiębiorcy (instytucji finansowej) godzące lub sprzeczne z prawem lub dobrymi obyczajami, polegające na proponowaniu konsumentom nabycia usług finansowych, które nie odpowiadają potrzebom tych konsumentów ustalonym $\mathrm{z}$ uwzględnieniem dostępnych przedsiębiorcy informacji $\mathrm{w}$ zakresie cech tych konsumentów, lub proponowaniu nabycia tych usług w sposób nieadekwatny do ich charakteru. Zdefiniowana praktyka jest niczym innym jak tytułowym missellingiem, nazywanym przez UOKiK także nieuczciwą sprzedażą. Cytowany przepis jest niezwykle rozbudowany i zawiera w sobie kilka bardzo ważnych elementów, w tym także behawioralnych. Te ostatnie widoczne są w części poświęconej konieczności oceny potrzeb konsumentów, ustalonych z uwzględnieniem dostępnych przedsiębiorcy cech indywidualizujących tych konsumentów. Tym samym oznacza to konieczność uwzględnienia przez sprzedającego w procesie decyzyjnym związanym ze sprzedażą przez niego określonej usługi indywidualnych cech jego nabywcy - i to w sytuacji, gdy nie zostały one przez prawodawcę wskazane. Uprzedzając dalszy wywód na ten temat, przypuszczać należy, że w katalogu owych cech znaleźć się powinny: wiek, zdolność dostrzegania ryzyka, wykształcenie, a być może i dotychczasowa zdolność kredytowa.

W uzasadnieniu projektu ustawy ${ }^{39}$, która wprowadziła do polskiego porządku prawnego instytucję zakazu missellingu, a więc sprzedaży produktów finansowych niedopasowanych do potrzeb konsumenta, wskazywano z jednej strony na znaczenie rynku finansowego i ryzyko, jakie on generuje, a $z$ drugiej na wzrost w ostatnich latach wykorzystania tej niekorzystnej praktyki na rynku polskim. Wskazano m.in. problem umów ubezpieczeniowych z ubezpieczeniowym funduszem kapitałowym $(\mathrm{UFK})^{40}$, polisolokat ${ }^{41}$, kredytów hipotecznych denominowanych

finansowym. Aktualne tendencje i problemy dyskusyjne, pod red. E. Fojcik-Mastalskiej, E. Rutkowskiej-Tomaszewskiej, Wrocław 2011, s. 137-147.

${ }^{39}$ Uzasadnianie projektu ustawy z dnia 5 VIII 2015 r. o zmianie ustawy o ochronie konkurencji i konsumentów oraz niektórych innych ustaw, http://www.sejm.gov.pl/ sejm7.nsf/druk.xsp?nr=3662 (dostęp: 3 IX 2017).

${ }^{40}$ Warto polecić $\mathrm{w}$ tym miejscu publikację, w której w wyczerpujący sposób poddane zostały analizie UFK. Zob. P. Sury, Nieprawidłowości dystrybucji tzw. polisolokat a znamiona przestępstwa oszustwa, "Prokuratura i Prawo” 2016, nr 7-8, s. 228-254.

${ }^{41}$ A. Michór, Ubezpieczenia na życie z ubezpieczeniowym funduszem kapitałowym a ochrona konsumenta, „Bezpieczny Bank” 2015, nr 1, s. 156-160. 
w walutach obcych, a także cieszących się dużą popularnością wśród osób gorzej sytuowanych i starszych tzw. chwilówek (w których przypadku koszt liczony stopą RRSO potrafi dojść do kilkudziesięciu tysięcy procent!). Pierwszy z wymienionych przykładów, czyli UFK, stał się także bodźcem do podjęcia podobnych kroków walki z missellingiem w Wielkiej Brytanii, którą przekornie uznać można by za jego ojczyznę. Tam bowiem w roku 2001 wybuchł skandal, który dotyczył polis dodawanych do kredytów bankowych, tzw. PPI (ang. Payment Protection Insurance), które $\mathrm{w}$ swym założeniu miały stanowić zabezpieczenie przed skutkami zaprzestania spłaty przez konsumentów ich zobowiązań wobec sektora bankowego, co mogło mieć swoje źródło w chorobie czy też utracie pracy ${ }^{42}$. Produkt ten miał być zarazem wzorcowym przykładem współpracy sektora bankowego i ubezpieczeniowego, promowanej pod nazwą bancassurance ${ }^{43}$. Z danych przytaczanych w literaturze wynika, że przez około dziesięć lat sprzedano $34 \mathrm{mln}$ tego rodzaju polis, które przyniosły brytyjskim instytucjom finansowym zysk w kwocie 14 mld funtów. Wraz z wybuchem kryzysu finansowego w 2008 r. okazało się jednak, że "król jest nagi”, a PPI, zamiast chronić konsumentów, były przede wszystkim sposobem efektywnego zarobku dla sektora finansowego $^{44}$. Znalazło to wyraz m.in. w skargach i reklamacjach skierowanych do brytyjskiego organu nadzoru finansowego, których, jak się szacuje, złożonych zostało w latach 2006-2013 aż 33,1 $\mathrm{mln}^{45}$. Misselling, jako

${ }^{42}$ Więcej na ten temat w: E. Wierzbicka, Misselling bariera rozwoju ubezpieczeń w Polsce, "ZN WSH Zarządzanie" 2016, nr 2, s. 317-318.

${ }^{43}$ P. Sury, Praktyka bancassurance a przepisy karne ustawy o pośrednictwie ubezpieczeniowym, "Prokuratura i Prawo" 2014, nr 10, s. 103-122. Zob. także B. Mrozowska, Bancassurance - regulacje prawne i samoregulacja rynku, "Prawo Asekuracyjne” 2012, nr 3, s. 30-47; E. Rutkowska-Tomaszewska, Nieuczciwe praktyki na rynku bankowych ustug konsumenckich, Warszawa 2011, s. 166-169; M. Orlicki, O potrzebie rekomendacji U i wytycznych dystrybucyjnych Komisji Nadzoru Finansowego dla regulacji wspótpracy banków i ubezpieczycieli, w: Prawo rynku finansowego. Doktryna, instytucje, praktyka, pod red. A. Jurkowskiej-Zeidler, M. Olszaka, Warszawa 2016, s. 192-204; D. Maśniak, Znaczenie rekomendacji Komisji Nadzoru Finansowego (U) wydanej dla banków dotyczacej dobrych praktyk w zakresie bancassurance oraz wytycznych Komisji Nadzoru Finansowego dla zakładów ubezpieczeń dotyczacych dystrybucji ubezpieczeń dla regulacji rynku ubezpieczeniowego, w: Prawo rynku finansowego..., s. 176-191.

${ }^{44}$ Raport Rzecznika Finansowego. Ubezpieczenia na życie z ubezpieczeniowym funduszem kapitatowym, cz. II, Warszawa 2016, s. 69.

${ }^{45}$ P. Piesiewicz, Analiza złych praktyk brytyjskich instytucji finansowych - wnioski dla rynku polskiego, "Zarządzanie i Finanse, Journal of Management and Finance" 2014, vol. 12 , no. $3 / 2$, s. 27. 
nieuczciwa gra rynkowa, wątpliwa zarówno pod względem prawnym, jak i etycznym, prowadząca do oferowania i sprzedaży produktów finansowych $^{46}$, była zapewne jedną z przesłanek reformy systemu nadzoru nad rynkiem finansowym w Wielkiej Brytanii i wyodrębnienia funkcjonującego do dziś Financial Conduct Authority (FCA), jako wyspecjalizowanego organu będącego częścią tamtejszego systemu nadzoru nad rynkiem finansowym ${ }^{47}$. Organ ten stanowi swego rodzaju novum i jest zarazem, jak się uważa, przykładem funkcjonowania modelu nadzoru opartego na koncepcji twin peaks, która propagowana była przed laty także w literaturze przedmiotu ${ }^{48}$. W uproszczeniu, sprowadza się ona do istnienia dwóch filarów nadzorczych, z których pierwszy czuwa nad bezpieczeństwem i stabilnością rynku finansowego, podczas gdy drugi ma za zadanie chronić konsumentów i inwestorów, w tym także infrastrukturę rynku finansowego. Model brytyjski zakłada istnienie odpowiednio Prudential Regulatory Authority i wspominanego Financial Conduct Authority oraz w określonym zakresie inicjatywę Banku Anglii ${ }^{49}$.

Przykład brytyjski nieprzypadkowo przywoływany zostaje w tym miejscu. Bo choć problematyka zapobiegania missellingowi na rynku usług finansowych powierzona została Prezesowi UOKiK, to jednak powstaje pytanie o sens tego rodzaju rozwiązania w sytuacji, gdy faktycznym nadzorca rynku finansowego w Polsce jest Komisja Nadzoru Finansowego (KNF), w której ramach z powodzeniem od lat funkcjonuje Departament Ochrony Klientów. Co więcej, przegląd systemu ochrony konsumenta na polskim rynku finansowym wskazuje, że nad jego bezpieczeństwem, poza wspomnianymi UOKiK i KNF, czuwają także:

\footnotetext{
${ }^{46}$ Raport Rzecznika Finansowego. Ubezpieczenie sprzętu elektronicznego, s. 69.

47 System ten został szczegółowo omówiony w publikacji P. Zawadzkiej, Model nadzoru finansowego i sadowa kontrola decyzji nadzorczych w Wielkiej Brytanii, w: Prawo finansowe wobec wyzwań XXI wieku, pod red. J. Glinieckiej, A. Drywy, E. Juchniewicza, T. Sowińskiego, Warszawa 2015, s. 131-139.

${ }^{48}$ Recent Developments in Supervisory Structures in EU and Acceding Countries, European Central Bank, October 2006, s. 1-4; M. Tylor, The Road from 'Twin Peaks' - and the Way Back, "Connecticut Insurance Law Journal" 2009, vol. 16, iss. 1, s. 61-95; E. Ferran, The Break-up of the Financial Services Authority, "Oxford Journal of Legal Studies" 2011, vol. 31, iss. 3, s. 463; E. Wymeersch, The Structure of Financial Supervision in Europe. About Single, Twin Peaks and Multiple Financial Supervisors, "European Business Organization Law Review” 2007, vol. 8, iss. 2, s. 237-306.

${ }^{49}$ Szczegółowo na ten temat zob. P. Zawadzka, Model nadzoru finansowego... Zob. także M. Ochwat, Nadzór nad rynkiem finansowym w Wielkiej Brytanii, „Monitor Prawa Bankowego" 2016, nr 9, s. 46-65.
} 
miejscy i powiatowi rzecznicy konsumentów, Rzecznik Finansowy ${ }^{50}$, Inspekcja Handlowa, Europejskie Centrum Konsumenckie, jak również organizacje pozarządowe i sądy polubowne (przy KNF i Związku Banków Polskich). Rozpatrując ochronę w szerszym wymiarze, do wymienionych podmiotów dodać można by jeszcze Narodowy Bank Polski i Komitet Stabilności Finansowej. Mimo to, jak wskazuje raport Najwyższej Izby Kontroli (NIK) o ochronie klientów rynku finansowego w latach 2011-2013 ${ }^{51}$, ochrona ta była nieskuteczna i nie stwarzała konsumentom możliwości efektywnej ich ochrony. W raporcie tym mimo pozytywnej oceny aktywności poszczególnych podmiotów wymienionych powyżej zwrócono uwagę na dwa podstawowe problemy: brak jasnego podziału kompetencji pomiędzy poszczególnymi podmiotami ochrony praw konsumentów usług finansowych oraz brak efektywnej współpracy pomiędzy nimi. Co gorsza, wskazano, że według badań Komisji Europejskiej poziom zaufania konsumentów do instytucji publicznych w Polsce chroniących konsumentów należał do najniższych w Unii Europejskiej ${ }^{52}$. Ponadto zdaniem NIK podział kompetencji w ramach systemu ochrony praw klientów podmiotów rynku finansowego nie jest dla konsumentów tego rynku dostatecznie przejrzysty. Dlatego niejako na marginesie rozważań o missellingu warto zadać pytanie, czy polski rynek finansowy nie doszedł już do momentu, w którym ochrona konsumenta usług finansowych powinna zostać powierzona jednemu podmiotowi - polskiemu odpowiednikowi FCA - czyli Komisji Ochrony Klientów Rynku Finansowego. Być może powstać mogłaby ona jako efekt planowanej reformy systemu nadzoru finansowego w Polsce. Innym rozwiązaniem byłoby wzmocnienie $w$ tym obszarze kompetencji KNF, która objęłaby swym nadzorem również nadużycia w postaci missellingu. Organ ten mógłby wówczas korzystać z uprawnień posiadanych obecnie przez Prezesa UOKiK, takich jak np.: możliwości publikowania bezpłatnych komunikatów dotyczących zjawisk mogących stanowić istotne zagrożenie dla interesów konsumentów oraz ostrzeżeń w publicznym radiu i telewizji (art. 31c u.o.k.i.k.) ${ }^{53}$, a także niezwykle ważnej i potrzebnej instytucji tzw. „tajemniczego klienta” (art. 105ia u.o.k.i.k.),

${ }^{50}$ B. Bronisz, Ustawa o rozpatrywaniu reklamacji przez podmioty rynku finansowego i orzeczniku finansowym, "Monitor Prawa Bankowego" 2016, nr 3, s. 67-77.

${ }^{51}$ Raport Najwyższej Izby Kontroli, Funkcjonowanie systemu ochrony praw klientów podmiotów rynku finansowego, Warszawa 2014.

52 Ibidem, s. 7.

${ }^{53}$ Por. art. 4 ust. 1 pkt 4 Ustawy z dnia 21 VII 2006 r. o nadzorze nad rynkiem finansowym (tekst jedn. Dz.U. 2012, poz. 1149 ze zm.). 
która stanowić może skuteczny oręż w walce z nieetycznymi działaniami instytucji finansowych.

Wymienione przykłady znajdują się obecnie w zakresie kompetencji Prezesa UOKiK i są elementem komentarzy przedstawicieli doktryny, podobnie jak inne rozwiązania przyjęte w przepisie art. 24 ust. 2 pkt 4 u.o.k.i.k., normującym zakaz missellingu. Główne wątki tej dyskusji dotyczą: problemu zdefiniowania pojęcia "usługi finansowej”, mającego zasadnicze znaczenie dla możliwości zastosowania przytoczonego przepisu $^{54}$, wskazania dobrych obyczajów jako przesłanki oceny, a także wspomnianej możliwości nakładania się kompetencji organów odpowiedzialnych za nadzór nad rynkiem usług finansowych oferowanych konsumentom oraz sposobu weryfikacji przez przedsiębiorcę rzeczywistych potrzeb klientów ${ }^{55}$. Ze względu na tematykę i treść niniejszej publikacji ostatnią z wymienionych kwestii uznać należy za wymagająca większej uwagi. Jak bowiem należy ocenić adekwatność usługi i potrzeby konsumenta? Mimo że, zdaniem projektodawców zakazu missellingu, ocenie UOKiK podlegać powinien sposób oferowania i sprzedaży usług finansowych (jego zgodność z dobrymi obyczajami i prawem), to jednak bez uwzględnienia behawioralnych cech konsumenta (jego potrzeb) nie sposób w sposób obiektywny dokonać ewaluacji całego procesu. I choć w czasie prac nad analizowaną nowelizacją proponowano wskazanie przykładowych cech odbiorcy usługi (takich jak wiek, stan zdrowia, doświadczenie, wiedza dotycząca usług finansowych oraz sytuacja

${ }^{54} \mathrm{~W}$ prawie rynku finansowego, definiując pojęcie „usługi finansowej”, wskazuje się m.in. przepis art. 2 pkt b) dyrektywy 2002/65/WE Parlamentu Europejskiego i Rady dotyczącej sprzedaży konsumentom usług finansowych na odległość, w którym prawodawca europejski za usługę finansową uznał wszelkie usługi o charakterze bankowym, kredytowym, ubezpieczeniowym, emerytalnym, inwestycyjnym lub płatniczym. Zob. Dyrektywa 2002/65/WE Parlamentu Europejskiego i Rady z dnia 23 IX 2002 r. dotycząca sprzedaży konsumentom usług finansowych na odległość oraz zmieniająca dyrektywę Rady 90/619/EWG oraz dyrektywy 97/7/WE i 98/27/WE (Dz.Urz. UE L 271/16 z 9 X 2002 r. ze zm.).

${ }^{55}$ Zostały one omówione szczegółowo w publikacji autorstwa J. Sroczyńskiego, Misselling: nowy rodzaj zakazanej praktyki naruszającej zbiorowe interesy konsumentów, „Przegląd Ustawodawstwa Gospodarczego" 2016, nr 4, s. 26-31. Poza tym na uwagę zasługują także publikacje: J. Orlicka, Zakaz stosowania klauzul abuzywnych i missellingu w znowelizowanej ustawie o ochronie konkurencji i konsumentów, „Prawo Asekuracyjne” 2015, nr 4, s. 36-47; C. Banasiński, M. Bychowska, Między efektywnością administracji a pewnościa sytuacji prawnej przedsiębiorców, "Internetowy Kwartalnik Antymonopolowy i Regulacyjny” 2015, nr 4, s. 59-73; A. Wędrychowska-Karpińska, A. Wiercińska-Krużewska, Komentarz do art. 24 ustawy o ochronie konkurencji i konsumentów, w: Ustawa o ochronie konkurencji i konsumentów. Komentarz, pod red. A. Stawickiego, E. Stawickiego, Warszawa 2016, s. 686-697. 
materialna), ostatecznie $\mathrm{z}$ nich zrezygnowano. $\mathrm{W}$ takiej sytuacji to po stronie instytucji finansowej pozostawiono obowiązek oceny cech jej klienta. Podkreślić przy tym należy wyraźnie, że w procesie tym nie tyle chodzi o ocenę wadliwości czy też bezprawności usługi, ale o ocenę potrzeb konsumenta oraz dostosowania do niego formy prezentacji tejże usługi i podjęcia ostatecznej decyzji o możliwości jej sprzedaży. Proces postępowania powinien więc przebiegać w sposób następujący: najpierw dokonuje się charakterystyki behawioralnej konsumenta, a następnie, jeżeli jej wynik będzie pozytywny, można przystąpić do poinformowania go w sposób adekwatny o szczegółach oferowanej usługi ${ }^{56}$. Problemy, jakie się $\mathrm{w}$ tego rodzaju procedurze pojawiają, to: sposób dokonania testu charakterystyki behawioralnej oraz zakres przekazywanej informacji. Jak powinien postąpić pracownik instytucji finansowej w sytuacji negatywnej oceny klienta, który mimo wszystko zażąda kupna usługi ${ }^{57}$ Czy możliwe jest stworzenie efektywnego systemu ochrony przed pokusami płynącymi z missellingu, przy uwzględnieniu scharakteryzowanego wcześniej zjawiska "zamknięcia w sieci"? Odpowiadając na powyższe pytania, należy ponownie zaproponować zmianę optyki w postrzeganiu konsumenta i dążenie do wypracowania wzorca konsumenta świadomego, a więc ponoszącego część ryzyka wynikającego z określonej inwestycji. Jego ocena powinna jednak zostać dokonana na podstawie przygotowanego we współpracy z psychologami i socjologami testu charakterystyki behawioralnej, który podlegałby rzetelnej weryfikacji i akceptacji przez organ nadzoru. Mimo, zapewne, zdecydowanego sprzeciwu sektora finansowego rzetelność przeprowadzania wskazanej oceny należałoby wspomóc wzmożonymi kontrolami przy zastosowaniu instytucji "tajemniczego klienta”. Z jednej strony tworzyłoby to tzw. atmosferę konstruktywnej niepewności co do chwili ewentualnej kontroli, a z drugiej - miałoby wymiar wychowawczy i żywić należy nadzieję, że doprowadziłoby do wypromowania praktyk etycznych w sektorze instytucji finansowych, a tym samym do zwiększenia zaufania do systemu finansowego. Ostatnim elementem opisywanego procesu jest zakres przekazywanej informacji i wystąpienie

${ }^{56}$ Zgodzić się należy z twierdzeniem J. Sroczyńskiego, że „nieadekwatność proponowania może polegać na wyolbrzymianiu korzyści kosztem ryzyk, przesadnym przedstawianiu usługi jako zmieniającej życie nabywcy, wybawiającej go od wszelkich kłopotów finansowych, itp." (J. Sroczyński, Misselling..., s. 27).

${ }_{57}$ Zob. rozwiązania zaproponowane przez KNF w dokumencie Rekomendacje dla zakładów ubezpieczeń dotyczace badania adekwatności produktu, Warszawa 2016. 
ewentualnego deliktu informacyjnego po stronie instytucji finansowej. Kwestia ta jest niezwykle skomplikowana, bowiem - jak słusznie uważa A. Chłopecki - „brakuje automatycznego związku między brakiem informacji wymaganej prawem a missellingiem. Brak tego związku wynikać może $z$ tego, że dany produkt finansowy mógł być adekwatny dla danego klienta mimo braku właściwej informacji, której klientowi temu nie udzielono. Po drugie, brakuje automatycznego związku między missellingiem a szkodą. Produkt mógł być nieadekwatny dla danego klienta, a jednak przynieść mu zysk. Rozumowanie ujmujące delikt informacyjny jako automatyczną (współ)przyczynę prowadzącą do szkody jest rażącym uproszczeniem. Należy jednak ponownie podkreślić, że delikt informacyjny przerzuca ciężar dowodu na dokonującego deliktu $[\ldots]^{\prime 58}$. Zakres przekazywanych informacji powinien być więc wystandaryzowany przez organy nadzoru (KNF) w odniesieniu do konkretnych instrumentów finansowych, a w przypadku instrumentów „szytych na miarę" otrzymać stosowny certyfikat informacyjny (etyczny?) od tego organu. Zaproponowane rozwiązanie potwierdza tezę o konieczności dążenia do stworzenia w Polsce specjalistycznego podmiotu nadzoru chroniącego interesy klientów rynku finansowego, który w określonych sytuacjach mógłby zakazać oferowania określonych rodzajów instrumentów ${ }^{59}$.

\section{Podsumowanie}

Oceniając zasadność wprowadzenia do polskiego systemu prawnego zakazu nieuczciwej sprzedaży, jak powszechnie określa się instytucję missellingu, uznać należy zasadność tego rodzaju działania. Nadużycia na rynku finansowym, obecna na nim pokusa nadużycia czy też

${ }^{58}$ A. Chłopecki, Szkoda z tytułu utraty wartości instrumentu finansowego, "Glosa” 2017, nr 2, s. 35-36.

${ }^{59}$ Takie rozwiązanie dopuszcza prawodawca europejski $\mathrm{w}$ rozporządzeniu nr 600/2014 z dnia 15 V 2014 r. w sprawie rynków instrumentów finansowych oraz zmieniającym rozporządzenie (EU) nr 648/2012, OJ L 173/84. W pkt 29 preambuły tego aktu stanowi się o możliwości uzupełnienia uprawnień właściwych organów nadzorczych o specjalny mechanizm wprowadzania zakazu lub ograniczenia wprowadzania do obrotu, dystrybucji i sprzedaży wszelkich instrumentów finansowych lub lokat strukturyzowanych powodujących poważne zagrożenia dla ochrony inwestorów, dla prawidłowego funkcjonowania i integralności rynków finansowych lub rynków towarowych lub dla stabilności całego systemu finansowego lub części tego systemu. 
asymetria informacji w połączeniu z rola, jaką pełnią w życiu codziennym współczesne rynki finansowe, wymuszają konieczność zwiększenia ochrony słabszych ich uczestników, czyli konsumentów. Mimo że polityka ochrony konsumenta realizowana jest w Unii Europejskiej (i w Polsce) od kilkudziesięciu lat, to jednak specyfika, innowacyjność i elastyczność rynku finansowego stanowią wyzwanie dla prawodawcy. Nie jest bowiem zadaniem łatwym ująć w ramy prawne wyszukane rodzaje instrumentów finansowych, a co dopiero uregulować zachowania ludzkie. Jednak dorobek nauk behawioralnych, a za taką z całą pewnością uznać należy prawo, pozwala na wykorzystanie w procesie tworzenia i stosowania regulacji finansowych określonych rozwiązań, będących efektem badań prowadzonych przez przedstawicieli tych nauk. Wymaga to jednak interdyscyplinarnego podejścia i zmiany myślenia o prawie oraz człowieku, którego ono dotyczy. I choć, jak pokazuje zaprezentowany w artykule przykład missellingu, nie jest to zadanie łatwe, to jednak nie jest ono niemożliwe do zrealizowania. Nie byłoby bowiem zakazu missellingu, gdyby nie aktywność człowieka, jego kreatywność, ale i żądza zysku, która od wieków doprowadzała do kryzysów. Kryzysów, które zazwyczaj były przyczynkiem do refleksji i wprowadzenia nowych, lepszych rozwiązań - choć niestety, nie zawsze reguła ta odnosiła się do rynku finansowego.

\section{THE PROHIBITION OF MISSELLING AS AN EXAMPLE OF THE APPLICATION OF A BEHAVIOURAL CONCEPTION OF LAW}

\section{S u m mary}

This article concerns the institution of misselling introduced recently to the Polish legal system. Misselling has been commonly defined as dishonest sale. Currently, the solution adopted by the Polish legislator applies only to financial services provided by financial institutions to consumers. This regulation is not extensive but it has already stirred a lively debate among the representatives of legal practice and doctrine. This article is a voice in the discussion and its purpose is to identify the public law aspect of the solutions adopted and propose certain actions to be taken at the level of the regulated and the regulating entities and which would account among other things for the new, behavioural way of perceiving a consumer as an informed subject even if not always rational. The need for the evolution of the paradigm of a rational consumer, which is a challenge for the contemporary legislator, has been dictated by the experience gained so far as well as by the changing reality. The market today offers a range of new financial instruments which while being innovative very frequently carry extreme risk. The intensive and sometimes 
intrusive advertising of these instruments offered to "rational consumers" uses different persuasive marketing techniques and may in effect result in a potential loss of stability and security of the financial market. Therefore while implementing the stabilisation narrative promoted within the European Union, legislative bodies in Member States adopt solutions like misselling which are intended to reduce at least partly the risk of another crisis in the financial sector. Its sources go back to the conception of homo oeconomicus, that is a rational consumer who based on the information provided is capable of making a rational decision that is best for him. However, as experience and history show, this attitude is too idealistic and needs being redefined. Developing an optimal conception of an informed consumer requires an interdisciplinary approach which apart from the legal and economic elements will take into account the experiences of other branches of science, such as sociology or psychology as well.

Keywords: misselling - informed consumer - behavioural conception of law financial market law 